\title{
QUEER AZTLÁN IN CHERRÍE MORAGA'S THE HUNGRY WOMAN: A MEXICAN MEDEA
}

\author{
Allison Ramay \\ Pontificia Universidad Católica de Chile
}

\begin{abstract}
Drawing on Cherríe Moraga's semi-autobiographical writings and varied scholarly work, this article contends that in her play, The Hungry Woman: A Mexican Medea (2001), she not only critiques patriarchal heteronormativity, but she goes further by naming the necessary elements for a society in which her "Queer Aztlán" (1993), would be possible. Through a close reading of The Hungry Woman: A Mexican Medea (2001), this article demonstrates that the play not only focuses on the necessary deconstruction of patriarchal nationalism, but it also offers the unexpected seeds of change, found in the secondary character of Luna. By shifting our focus onto this character, we may better appreciate Moraga's forward thinking and the kernels of "Queer Aztlán" expressed in this play.
\end{abstract}

KeYwords: "Queer Aztlán,” Medea/Coyolxauhqui/Coatlicue/Huitzilopochtli, Chac-Mool, The Hungry Woman, Aztlán, Patriarchal Nationalism.

\section{LA AZTLÁN QUEER EN THE HUNGRY WOMAN: A MEXICAN MEDEA DE CHERRÍE MORAGA}

\section{RESUMEN}

Considerando las obras semi-autobiográficas de Cherríe Moraga y los textos críticos de académicos, en este artículo mantenemos que en su obra dramática The Hungry Woman: A Mexican Medea (2001), Moraga no solo ofrece una crítica hacia la heteronormatividad patriarcal, sino que va más allá; nombra los elementos necesarios para una sociedad en la cual su concepto de "Queer Aztlán” (1993) sería posible. En la lectura que ofrecemos de esta obra, demostraremos que The Hungry Woman brinda semillas inesperadas de cambio a través del personaje secundario de Luna. Al cambiar nuestro enfoque hacia este personaje es posible que apreciemos mejor la visión de futuro de Moraga y las simientes de la noción de "Queer Aztlán" dentro de ella.

Palabras Clave: "Queer Aztlán,” Medea/Coyolxauhqui/Coatlicue/Huitzilopochtli, ChacMool, The Hungry Woman, Aztlán, nacionalismo patriarcal. 
Xicana lesbian author and scholar Cherríe Moraga is renowned for having laid the foundation for Xicana written expression and resistance. From her earliest work in This Bridge Called My Back (1981) to her most recent Native Country of the Heart: A Memoir (2019), Moraga has recovered stories from the past and used them to shape new images and words for the present and future. Of her numerous multigenre plays, poems, essays and anthologies, one of her most complex works is The Hungry Woman: A Mexican Medea (2001), which combines Catholic, Greek and pre-Columbian myths about women to demonstrate the patriarchal nationalism embedded within them. Most scholars to analyze this play have focused on the significance of Medea, the play's protagonist, whose actions signal an end to patriarchy. Drawing on the author's writings, both before and after the publication of The Hungry Woman, and that of critics, this article suggests that through the secondary character of Luna, who has received little attention from scholars, we find the playwright's articulation of an alternative understanding of nationalism.

The Hungry Woman: A Mexican Medea is a complex treatment of overlapping myths, temporalities and spaces. While Medea's most evident connection is with Euripides's Medea, she also shares traits with Malinche, La Llorona and the Aztec goddess Coatlicue (known in the play as the Hungry Woman). All these figures have been used to limit female behavior, particularly those that could disturb or disrupt patriarchal order. In this play, Moraga explodes that order by fashioning a Medea who resignifies each of the mythical figures previously mentioned. She betrays the heteronormative rules in place, echoing Malintzin, the translator and lover of Spanish conquistador Hernán Cortés, and kills her child, like La Llorona and the Greek Medea, but for something bigger than revenge as this article contends.

In The Hungry Woman, Medea is an ex-revolutionary, who helped found Aztlán as a separate nation within the United States. The revolution defended aboriginal rights and anyone who supported the cause was allowed to stay within the territory. But after several years, hierarchies were formed between men and women, while all queer people were forced into exile. Sometime in between that period, Medea falls in love with a female stonemason, Luna. Once the heteronormative and patriarchal laws are put into place, the lesbian lovers are exiled to Phoenix, Arizona, (depicted as a wasteland) together with Medea's son, Chac-Mool, and her grandmother, Mama Sal. One of the conflicts centers on Chac-Mool, who has decided to return to Aztlán to be with his father. His return means that he will contribute to patriarchal nationalism, the very system of thought that exiled them. Jasón, his father, can only own land in Aztlán if Chac-Mool lives with him, because he, and not his father, has the proper indigenous blood quantity as part-Yaqui Indian and therefore his presence is instrumental rather than based on genuine fatherly love. In a symbolic act to interrupt and abolish the cycle, Medea ends Chac-Mool's life by giving him atole made of blue corn that, she says, will make him sleepy. Shortly after his death, Chac-Mool comes back in the form of a spirit, gives her a similar drink and tells her he will take Medea "home." Crucially, upon dying, each figure is held in a pieta image. First, Medea holds Chac-Mool and, later, Chac-Mool holds Medea, symbolizing the renewed life sought by Medea: an end to the machismo that overtook Aztlán and destroyed it as a promise land for all. 
The exorbitantly extreme price paid by Medea to end patriarchal nationalism can be read in multiple ways. Some argue that it expresses the unlikelihood that heteronormativity will ever be truly defeated. In a fascinating discussion on death as a sort of gift in The Hungry Woman, Tania González argues that, "By playing with murder as an act of-and death as a space of-subversion of patriarchal power, Moraga highlights the difficulties in escaping ideologies that perpetuate discourses of difference" (50). And yet, Moraga seems certain that the best way to imagine a world without patriarchy is through a story as powerful and emotionally charged as the many stories that have killed women's sexuality and agency. In an interview with Maria Antònia Oliver-Rotger, Moraga asks: "Well, if traición was the reason [for Euripides's Medea to kill her children], could infanticide then be retaliation against misogyny, an act of vengeance not against one man, but man in general for a betrayal much graver than sexual infidelity: the enslavement and deformation of our sex?" (11). In other words, for Moraga, a story that rewrites Euripides's myth, would emphasize the point that true liberation for women has yet to be achieved and that enormous sacrifices are still needed.

Patriarchy, as a system in need of dismantling, appears forcefully in much of Moraga's writing on the 1960s and 1970s Chicano Movement. As Professor Emeritus Francisco A. Lomelí states, "the idea of a historic-geographical Aztlán served as the most unifying force in the emerging cultural renaissance" (2). It created a sense of self-determination, unity and a common dream. However, according to Moraga, the Movement "never accept[ed] openly gay men and lesbians among its ranks" ("Queer" 255). Heterosexual men maintained the most important leadership positions, invoking stories that would keep Chicanas "silent and sexually passive" ("Queer" 260). New and challenging stories, such as The Hungry Woman, speak back to this trajectory of patriarchal nationalism, in part, by placing death at the center. As Moraga says in her 2007 interview with Oliver-Rotger, "I chose tragedy, 'because it teaches deeper and harder than happy' " (10). This tragedy uniquely places queer desire at the center and, perhaps ironically, can be read as expressing hope for the future of Xicanxs. As Michelle R. Martin-Baron shows in her consideration of a term she calls mythical enjambment (that is, the insertion of myths where they are not supposed to be, according to convention), one can find Moraga's utopic vision in the play's "recognition of multiple modes of oppression" (244). By overlapping and intertwining numerous myths of different origins, she also implies that there is a way to unravel them. In a related observation, Tanya González asserts that, 'While death may not seem like a positive 'beginning,' Moraga's play asserts that it can be a place to start imagining the world from a decolonized perspective. By telling history from that 'future space,' she is able to imagine another future without disappointment and disillusionment-a real place organized by love, but only reachable through death" (73). In line with these scholars, who understand The Hungry Woman as creating an opening for an imagined alternative future, this article argues that a new form of belonging becomes most visible in the figure of Luna. To best understand the significance of this character, we must consider the patriarchy held within her counterpart, Medea. 


\section{THE UBIQUITY OF PATRIARCHY}

The powerful and enduring phrase that Xicana women needed to "unlearn the puta/virgen dichotomy," coined by Gloria E. Anzaldúa, continues to resonate with feminists around the globe. The message is that patriarchy is based on binary divisions, embedded in the thinking, speech and practices of both men and women. In Moraga's play, this notion manifests itself in Medea, who is unable to detach herself completely from the patriarchal nationalism practiced in Aztlán. ${ }^{1}$ Medea states: "I still have allies there. People don't forget so easy. I'm building a bridge back. For both of us. I'll send for you" (1.9.47). Luna, however, is more realistic: "I am not the kind of revolutionary they are looking for" (1.9.47). ${ }^{2}$ Medea's inability to imagine a full life without Aztlán makes her unwilling to commit entirely to her relationship with Luna and this reflects Medea's hubris. During most of the play, and despite her profound disapproval of Aztlán's heteronormative laws, she is not capable of separating herself from it. In Jorge Manuel González's reading of the play, Medea's participation in heterosexist discourse could reflect "the possible origins of a liberated Aztlán caught in the contradiction of its machista revolutionary rhetoric" (134).

One element that makes Medea a complex character is that she is not blind to her internal contradictions and the contradictions she represents for Aztlán. Perhaps for this reason, she predicts her own death at the beginning of the play, much before the double death at the end:

I am the last one to make this journey. My tragedy will be an example to all women like me. Vain women who only know to be the beloved. Such an example I shall be that no woman will dare to transgress those boundaries again. ... I am the last one to make this crossing, the border has closed behind me. (1.8.46)

When she states that she only knows how to "be the beloved," she implies that she has not learned to fully love another. In her environment, loving a woman and a man involves two mutually-exclusive systems; a person cannot be a revolutionary in Aztlán and also be a lesbian, which means that she has not been able to give herself completely to any person or cause. Furthermore, heteronormativity is represented in the play as intimately connected to patriarchal nationalism (Aztlán and Jasón), and because she still loves the idea of Aztlán, she is partially complicit with it. Recognizing that she is part of both systems allows us to better understand the significance of her death at the conclusion of the play: her own passing is also needed for heteronormative and patriarchal nationalism to end.

${ }^{1}$ For a consideration of Medea as practicing patriarchal motherhood, see Jorge Manuel González's dissertation chapter "Sacrifice of the Primal Mother/Sister: Decolonial Horizons and the Dialectics of Death in Cherríe Moraga's The Hungry Woman: A Mexican Medea", 2011.

2 Tania González also agrees on this point: "Medea's refusal to commit to Jasón or Luna is less a reflection of her disillusionment with her idyllic understanding of love and of the nation-state, and more an inability to live outside of the nationalist construction" (57). 
We learn more about the subtle presence of patriarchy operating within Medea through the play's use of the Mesoamerican myth of Coatlicue, the Aztec goddess of creation and destruction. According to the stage directions, Act I opens with a chorus made up of Aztec women, who have died in childbirth ("Cihuatateo") and tell a shortened version of the Coatlicue myth, with an altar to this goddess in the backdrop. In the story, Coatlicue is impregnated by an eagle feather. Her children know that the gestating child is the God of War, Huitzilopochtli, and fearing him, Coatlicue's daughter, Coyolxauhqui, and her four hundred siblings, prepare a plan to kill their mother. However, Huitzilopochtli is warned about their plan by a hummingbird and as soon as he is born, he dismembers Coyolxauhqui, who is "banished to the darkness and becomes the moon" (Last Generation 73). References to this myth appear throughout the play. Crucially, Act II begins with a re-enactment of the Coatlicue myth where each of the play's characters is assigned to one of the myth's figures: Luna is the daughter/Coyolxauhqui, Medea is the mother/Coatlicue, and Chac-Mool is the son/Huitzilopochtli.

The primary problem with this myth, according to Moraga, is that it imposes symbolic violence on the relationship between mothers and daughters, a point she highlights in The Last Generation:

Here, mother and daughter are pitted against each other and daughter must kill male-defined motherhood in order to save the culture from misogyny, war, and greed. But el hijo comes to the defense of patriarchal motherhood, kills la mujer rebelde, and female power is eclipsed by the rising light of the Sun/Son. This machista myth is enacted every day of our lives, every day that the sun (Huitzilopochtli) rises up from the horizon and the moon (Coyolxauhqui) is obliterated by his light. (73)

In this myth, the mother is complicit with and facilitates a dominant and violent son, who represents a world based on binaries, where he is the strongest unit. In this scenario, mothers and daughters are not at peace, nor are siblings. In The Hungry Woman, though, this imbalance is symbolically avoided because Medea kills the son. Chac-Mool's death is the death of Huitzilopochtli, which leads to the end of heteronormative patriarchal nationalism, and Jasón will never own land or have descendants in Aztlán.

Beyond undoing the dichotomies implied in the myth by taking Huitzilopochtli out of it, Moraga also makes an important addition, which involves healing the mother-daughter wound. Immediately following the infanticide and before her own passing, Medea denounces Coatlicue for betraying her daughter, which she did when she allowed her son/Huitzilopochtli to murder her daughter/ Coyolxauhqui. Medea, then, proclaims allegiance to the daughter/Coyolxauhqui: "Ahora, she is my god. La Luna, la hija rebelde" (2.8.92). Indeed, Medea's antidote to age-old patriarchal violence is to transfer her loyalty to the daughter who never had the chance to have a proper relationship with the mother. In the play, this daughter is Luna. As Kathryn Quinn-Sánchez maintains, Medea offers "life and freedom to the goddess of the moon, and by extension to all women" (42). In this way, Medea has made an essential move toward abolishing the patriarchy within her. 
We know that Medea's new allegiance to the daughter/Coyolxauhqui, and also Luna, is important because the entire play culminates in a scene where the moon is fundamental. In the last scene, Chac-Mool comes back for Medea in the form of a spirit to "take her home." He gives her a drink made of powdered herbs, and when confused, Medea asks him where home is, he tells her to look at the moon. She attempts to do this, but complains, "The sun is too bright" (98). Eventually she sees the full moon and Chac-Mool repeats: "You're going home" (98). Medea's vision was at once eclipsed by the "sun," but then she is able to see her new home with the moon. So, unlike the Coatlicue myth, where Medea/Coatlicue is about to be murdered by her daughter, here quite the opposite occurs; she symbolically goes to rest with the daughter (the moon), together with the son/sun (Chac-Mool). By embracing Chac-Mool and Medea (read as Coyolxauhqui receiving Huitzilopochtli and Coatlicue), the three figures, who were pitted against each other in the Coatlicue myth, are now united. Moraga, also, resignifies the holy trinity entirely, placing the daughter as the one who lovingly holds the mother and the son in a relationship free of hierarchies.

\section{LUNA AS “QUEER AZTLÁN”}

The fact that the character of Luna continues to live in the physical world after the death of Medea and Chac-Mool is also important. Luna, who Moraga envisioned as just as much of a border figure as Medea (Oliver-Rotger 13), symbolizes alternative knowledge and renewed forms of belonging. As a lesbian, Luna has no chance of being welcomed back into Aztlán, and this could explain, at least in part, her sense of freedom and certainty her identity. Medea even seems to envy her: "You act so free" (1.9.48). Luna uses her freedom to help Medea, by trying to convince her to leave Jasón and Aztlán forever. She also attempts to rescue others. At one point, Luna illegally crosses into Aztlán and tells the Border Guard that she wanted to free "them." When the Border Guard asks "who?" she responds: "Ancient little diosas, the size of children's toys. They were trapped, sir, behind the museum glass. They belonged to us. ... I wanted to free my little sisters, trapped by history" (2.1.59). Luna's message is that by helping the "little diosas," or sculpted "sisters," return to their families, she could free them from the static space of the museum, a space that unjustly claimed ownership over their bodies and depleted the communities who depended on their power. Although we do not know the identity of the clay sculptures, the Aztecs believed that the tangible representation of deities held the teotl (or divine power) of the god themselves. Freeing them would, then, restore the community's strength.

Luna is somewhat successful in freeing these figures as her goal is to hold their hands, which she manages to do, but she is not able to convince Medea to let go of Aztlán. Mama Sal sees this clearly:

Mama SAL. When you're a girl, hija, and a Mexican, you can learn purty quick that you got only one shot at being a woman and that's being a mother. 
Luna. Tell Medea. She's the mother, not me.

MAma SAL. You go from a daughter to a mother, and there's nothing in between. That's the law of our people written como los diez commandmaents on the metate stone from the beginning of all time.

LunA. Well, that ain't my story.

Mama sal. Exactly. You go and change the law. You leave your mother and go out and live on your own...You learn how to tear down walls and put them up again. Hasta tu propia casa, you build with your own hands. (1.9.50)

While the burden of lesbianism is clear in that they have been banished to a wasteland, Luna is depicted as capable of creating something new, as a sculptor and as a person who does not adhere to heteronormative laws. Mama Sal's encouragement here for Luna to build her own house and set of laws, foreshadows the future that she may facilitate.

At the end of the play, Luna is the only figure remaining from the Coatlicue myth and she represents the possibility of an alternative future that she would not only build for herself, but for others as well. This is interesting because Luna's way of being in the world resembles Moraga's "Queer Aztlán," a concept she developed with Xicano poet Ricardo Bracho only a few years before the play was read for the first time to an audience. ${ }^{4}$ The two authors dreamed of a Chicano homeland that could "embrace all its people, including its jotería" ("Queer" 254). And Moraga adds that this nation would be based on an all-inclusive nationalism (as opposed to the conventional divisive nationalism), where one would find a range of people with different racial, sexual and gender expressions (264). Like the notion of Aztlán during the Chicano Movement, "Queer Aztlán" is not ambiguous about its Indian identity and adopts an indigenist worldview, where people " take the rights of indigenous peoples as the highest priority,' and who 'draw upon the traditions ... of native peoples the world over" (265).

Luna's character, in many ways, practices citizenship and an alternative form of nationalism as it would seem to work in "Queer Aztlán." The economy she represents is not of accumulation (capitalistic), but rather of subsistence, seen in her recommendation to Chac-Mool: "Plant corn. A single corn can produce enough grain to feed a person for a day" (1.1.13). Luna's reverence of the Aztec goddess Tonantzin, who connotes to mother earth, agriculture and human fertility, also demonstrates her closeness to the indigenous ways of being. Her knowledge of the earth's cycles and abundant harvest in a barren land, where corn would not typically survive, let alone flourish, also indicate her closeness to indigenous knowledge of

${ }^{3}$ In the essay, originally published in 1993, Moraga states: “'Queer Aztlán’ had been forming in my mind for over three years and began to take concrete shape a year ago in a conversation with poet Ricardo Bracho" (225).

${ }^{4}$ The first staged reading took place at Berkeley Repertory Theatre on April 10, 1995 (The Hungry Woman 5).

5 Moraga includes an endnote stating that, for Chicanos, joteria means "queer" folk. 
the land, which surpasses that of other characters, even the elderly Mama Sal, who is surprised by Luna's "experiment" to plant blue corn in Phoenix (1.4.30). Perhaps most importantly, her knowledge of maize brings her into a caring relationship with Chac-Mool; he asks her to teach him the harvest ritual for planting maize, which she does in an abandoned lot near their building. Chac-Mool understands that this knowledge is the foundation of the "real revolution" and he dreams of bringing that knowledge back to the misguided and deformed Aztlán.

To a degree, Chac-Mool and Luna are interdependent; he is the apprentice and she the mentor. Chac-Mool is furious, when he learns that Luna is no longer in Medea's life, right at the time of harvest: "Where is she? She doesn't even get to see it. She planted it. Why can't she see it? Why did you send her away?" (66). Their relationship is interrupted because of Medea's inability to commit to Luna, who consequently leaves her, and because of Chac-Mool's interest in returning to Aztlán, which leads Medea to end his life. Stated in another way, complementarity between Luna and Chac-Mool (moon and son) is not possible because of Medea's inability to separate herself from her own desire to return to Aztlán, and because of the laws in Aztlán that make Chac-Mool's return inevitable.

Although a relationship of complementarity between Luna and Chac-Mool is not completely achieved, we are led to imagine that such a relationship occurs in a future and perhaps spiritual world, when Chac-Mool takes Medea "home" to the moon. Some feminist scholars argue that when societies move toward a patriarchal structure, myths of complementarity between gods and goddesses are sometimes replaced by myths like the Coatlicue one, where there is an "ousting of a goddess by a male god" (qtd in Lara 105). This is an essential point because a move toward complementarity between Luna and Chac-Mool would mean an overhaul and the healing of the dichotomous relationship they exhibit in the Coatlicue myth of the moon and the sun. We could use the same concept to think about the relationship between the mother and the daughter: Medea as the mother/Coatlicue and Luna as daughter/Coyolxauhqui. They, too, require healing and unity, which seems symbolically possible in this new home with the moon. As readers/viewers, we are made to imagine that harmony is reached at the end of the play; patriarchy has not only come to an end, but an alternative collectivity, one that is multi-faceted and multi-dimensional, is left as an offering.

The moon/Coyolxauhqui is an important symbol for Xicanas' response to the historic Xicano Movement, because she resembles the fragmentation that lesbian and gay Xicanos felt, "that of being 'mutilated' by her brother" (Luna and Galeana 17). She is also symbolic of the "pain many Chicanas understood living under a system of patriarchy, but more so, having been literally 'sacrificed' by their Chicano brothers during the Chicano Movement of the 1960s-70s" (Luna and Galeana 17). ${ }^{6}$ In this play, Moraga rewrites her symbolism entirely for she is anything but the victim; she is, rather, a manifestation of the future that begins at the end of the play. In this

\footnotetext{
6 See also Judith L. Huacuja's "Borderlands Critical Subjectivity in Recent Chicana Art."
} 
way, her significance comes closer to Jennie Luna and Martha Galeana's translation of her name as she who prepares for and is a visual manifestation of ceremony (15). Similarly, in Moraga's telling, we may also understand the moon/Coyolxauhqui, who is Luna, as offering, the gift of preparing for and realizing ceremony.

If we think of death in the play as not necessarily physical, but rather as mental and spiritual and needed for rebirth-as Coatlicue, the goddess of death and rebirth implies-, then we can visualize the subtle proposal for the future implied at the end. In other words, death symbolizes not only the end of one kind of thinking, as Tania González aptly demonstrates, but also a shifting of minds toward the alternative, non-normative, queer ways of being, embodied specifically in Luna.

Moraga states that she first learned about Coatlicue from Anzaldúa (OliverRotger 12). Although Anzaldúa's writing on Coatlicue did not seem to influence Moraga, her interpretation of Coyolxauhqui may have. Anzaldúa explains that this daughter-goddess is similar to the art of composition: "tanto si estás componiendo una obra de ficción o tu propia vida como si estás componiendo la realidad, siempre significa que tomas piezas fragmentadas y las pones juntas, formando un todo que tenga sentido" (283). Crucially, Moraga's Luna is also not fragmented-as she appears in the pre-Colombian myth-, but represents a source of wholeness, capable of aiding others and creating new realities.

As a "pionera" writer, Cherríe Moraga states that she did not receive guidance from the generations before her regarding the past. In her most recent work, Native Country of the Heart (2019) she states: "Growing up, my elders, well-meaning, told my generation 'Go that way, hijos. Look north to your future.' They asked us to betray them, to forget them. 'Walk that way, mi' ja.' They didn't know the cost." (4). Moraga responds to this lack of guidance by dedicating her life to providing alternative stories to lead her readers into the future. In her interview with Oliver-Rotger, Moraga is in agreement with Toni Morrison, when she states that the colored artist's duty is to explore and make more accessible their versions of the past:

And unraveling history, the multitude of versions of the story, the story from multifarious perspectives, this is limitless. And how great is our task to remember if we are people of color artists ... Because our version of the story has never been told. Still. (Oliver-Rotger 15)

As we have seen in this play, Cherríe Moraga takes on the very difficult task of weaving together myths that have been told about women, in such a way that it will change the course of the present and future: "Because history in all its limitlessness determines the future" (15), she adds. The road map that Moraga creates for her readers/viewers leads not to a particular geographical space, but rather to a new understanding of collectivity and belonging: Aztlán's heteronormative nationalism is no longer available to organize Xicanx society. In the physical world, Luna may lead a group of people to practice farming based on indigenous practice and ritual, and create new laws that demand inclusivity in all of its many forms. Through the character of Luna, we now have a story of an alternative to national belonging. While Moraga's Luna is a fictional character, her collaborative, non-binary thinking reflects 
a refusal to settle, reminiscent of Paolo Freire's theory of radical hope in Daring to Dream. This is the future Moraga has worked toward for decades, and one that comes within reach in The Hungry Woman.

REVIEWS SENT TO AUTHOR: 27-6-2020; REVISED PAPER ACCEPTED FOR PUBLICATION: $15-9-2020$ 


\section{WORKS CITED}

Anthony, Adelina. "Cherríe Moraga by Adelina Anthony." BOMB Magazine, 1 Jan. 2007, https:// bombmagazine.org/articles/cherr\%c3\%ade-moraga/. Accessed 15 Feb. 2019.

AnZaldúa, Gloria E. Borderlands/La Frontera: The New Mestiza. $1^{\text {st }}$ ed., Spinsters/Aunt Lute, 1987.

Euripides. Medea. CreateSpace Independent Publishing Platform, 2010.

Freire, Paolo. Daring to Dream: Toward a Pedagogy of the Unfinished. Paradigm, 2007.

GonzÁlez, Manuel Jorge. Sacrifice of the Primal Mother/Sister: Decolonial Horizons and the Dialectics of Death in Cherrie Moraga's The Hungry Woman: A Mexican Medea. 2011. U of California, Berkeley, PhD Dissertation.

GonzÁlez, Tanya. "The (Gothic) Gift of Death in Cherríe Moraga's The Hungry Woman: A Mexican Medea." Chicana/Latina Studies 7/1 (2007): 44-77. https://www.academia.edu/4191152/ The_Gothic_Gift_of_Death_in_Cherr\%C3\%ADe_Moragas_The_Hungry_Woman_A_ Mexican_Medea_. Accessed 15 Feb. 2019.

Huacuja, Judith L. "Borderlands Critical Subjectivity in Recent Chicana Art." Frontiers: A Journal of Women's Studies 24/2-3 (2003): 104-21.

Lara, Irene. "Goddess of the Américas in the Decolonial Imaginary: Beyond the Virtuous Virgen/ Pagan Puta Dichotomy." Feminist Studies, The Chicana Studies 34/1-2 (2008): 99-127.

Lomelí, Francisco A. "Introduction. Revisiting the Vision of Aztlán: Origins, Interpretations, and Theory vis-à-vis Fact and Fiction." Aztlann: Essays on the Chicano Homeland, $2^{\text {nd }}$ edition. Ed. Rudolfo A. Anaya, Francisco A. Lomelí \& Enrique R. Lamadrid. U of Mexico P, 2017. 1-24.

Luna, Jennie, and Martha Galeana. "Remembering Coyolxauhqui as a Birthing Text." Regeneración Tlacuilolli, UCLA Raza Studies Journal 2/1 (2016): 7-32. https://escholarship.org/uc/ item/2dt752tn. Accessed 12 Feb. 2019.

Martin-Baron, Michelle R. "Mythical Enjambment in The Hungry Woman: Nation, Desire, and Cherríe Moraga's Utopic Turn.” Women \& Performance: A Journal of Feminist Theory 28/3-4 (2018): 239-258. doi: 10.1080/0740770X.2018.1524618. Accessed 21 June 2019.

Moraga, Cherríe. A Xicana Codex of Changing Consciousness: Writings, 2000-2010. Duke University, 2011.

Moraga, Cherríe. Native Country of the Heart: A Memoir. Farrar, Straus and Giroux, 2019.

Moraga, Cherríe. "Queer Aztlán: The Re-Formation of Chicano Tribe." Aztlán: Essays on the Chicano Homeland, $2^{\text {nd }}$ ed. Ed. Rudolfo A. Anaya, Francisco A. Lomelí \& Enrique R. Lamadrid, U of Mexico P, 2017. 253-272.

Moraga, Cherríe. The Hungry Woman: A Mexican Medea. $2^{\text {nd }}$ ed., West End Press, 2001.

Moraga, Cherríe. The Last Generation: Prose and Poetry. South End Press, 1993.

Moraga, Cherríe. \& Gloria E. Anzaldúa, eds. This Bridge Called my Back: Writings by Radical Women of Color. Kitchen Table, Women of Color Press, 1981.

Oliver-Rotger, Maria Antònia. “Voices from the Gap. Interview Cherríe Moraga.” University of Minnesota. 2009. https://conservancy.umn.edu/handle/11299/166372. Accessed 5 May 2020.

Quinn-SÁnchez, Kathryn. Identity in Latin American and Latina Literature: The Struggle to Self-Define in a Global Era Where Space, Capitalism, and Power Rule. E-book, Lexington Books, 2015. 
